\title{
The Influence of Human Needs in the Perspective of Maqasid al- Syari'ah on Zakat Distribution Effectiveness
}

\author{
Maheran Zakaria ${ }^{1}$ \\ ${ }^{1}$ Accounting Research Institute, Universiti Teknologi MARA, Malaysia \\ Correspondence: Maheran Zakaria, Accounting Research Institute, Universiti Teknologi MARA, Malaysia. \\ E-mail: maheran_642004@yahoo.com
}

Received: December 1, 2013 Accepted: December 17, 2013 Online Published: January 27, 2014

doi:10.5539/ass.v10n3p165

URL: http://dx.doi.org/10.5539/ass.v10n3p165

\begin{abstract}
The objective of this study is to investigate the influence of human needs in the perspective of Maqasid al-Syari'ah namely religion, physical-self, knowledge, family and wealth on zakat (almsgiving) distribution effectiveness. Approximately 350 sets of questionnaire were personally sent to zakat recipients of two programs conducted by Majlis Agama Islam Kelantan (MAIK) namely business assistance and living skill course in Malaysia. From this amount, 320 people responded, amounting to $91.43 \%$ response rate. Data were analysed using Structural Equation Modeling of AMOSS (Analysis of Moment structure) version 20. From the findings, it is concluded that all human needs in the perspective of Maqasid al-Syari'ah namely religion, knowledge, physical- self, family and wealth positively influence zakat distribution effectiveness. Hence, the study provides an insight to zakat institutions, policy makers and the public that the effectiveness of zakat distribution could not only be judged in terms of monetary value but also to other non-monetary values that include religion, physical life, knowledge, family and wealth.
\end{abstract}

Keywords: zakat distribution, effectiveness, human needs, Maqasid al-Syari'ah, recipients, Malaysia

\section{Introduction}

Zakat (Almsgiving) is one of the important instruments in Islamic economy system and plays significant roles in eliminating inequalities in the society. Muslims who possess surplus wealth are obligated to pay zakat and this fund is distributed to prescribed eight beneficiaries known as asnaf group with the priority given to the poor and needy. The general principle of zakah distribution has been laid down clearly in the Quran as underlined in Surah Al-Taubah verse 60 that states: "Alms are for the poor and the needy, and those employed to administer the (funds) for those whose hearts have been (recently) reconciled (to Truth) for those in bondage and in debt in the cause of Allah and for the wayfarer: (thus is it) ordained by Allah, and Allah is full of knowledge and wisdom".

The purpose of distributing zakat fund is to alleviate poverty, to protect the welfare, to improve economic hardship and to develop the infrastructure of Muslim society through the distribution of income and wealth from the wealthy to the needy. In Malaysia, the responsibility of the collection and distribution of zakat fund is empowered to zakat institutions of which every state has its own, totalling to 14 zakat institutions. Indeed, the effectiveness of zakat distribution managed by the zakat institutions has become the main concern of the Muslim society as they hope that the fund could free recipients from poverty or if not to improve their quality of living.

As noted, many studies have been conducted examining the effectiveness of zakat distribution based on economical perspective of zakat recipients that is level of income (Mujani, 2005; Ibrahim \& Salleh, 2006; Fuadah, 2006; Mohamad, 2008; Zakariah et al., 2010; Mahyudin \& Abdullah, 2011). If the income soars, zakat distribution is deemed effective. However, if otherwise, the distribution is judged as fail to meet its goal. The income is chosen as an indicator due to the perception that money could solve humans' needs including poverty. Despite it has been well accepted, this assessment receives high criticism. Many claim that this assessment is unfair because human needs are not only confined to monetary but also include non-monetary elements. In fact, they go beyond the notion of income and encompass social, religion, economic, knowledge and spiritual among others (Mohamad Saladin et al., 2010). According to Rosbi and Sanep (2011) a better assessment of human needs should be evaluated in the perspective of Maqasid al-Syari'ah that consists of religion, physical-self, knowledge, family and wealth and failure to attain these stipulated needs qualify a human to be poor. 
In addition, the assessment that is based only on income does not provide a fair evaluation of human needs. Those, who evaluate the effectiveness of zakat from this perspective, will limit the distribution of aids to the recipients and thus help them in terms of monetary assistance only. Nevertheless, apart from money, humans also need other forms of assistance such as religion, knowledge, comfort living, family and socialising, among others.

To date, it is noted that studies on zakat distribution effectiveness have been the interests of many scholars and researchers (Mujani, 2005; Fuadah, 2006; Ibrahim \& Salleh, 2006; Mohamad, 2008; Zakariah et al., 2010; Mahyudin \& Abdullah, 2011; Rosbi \& Sanep, 2011). However, few studies have been found to investigate the zakat effectiveness in a fair, holistic and comprehensive assessment. Being aware of the deficiency in the previous assessments, it is suggested that zakat distribution effectiveness is evaluated in a wider, more holistic approach. As such, this study aimed to adopt the human needs as stipulated in the perspective of Maqasid al-Syari'ah namely religion, physical-self, knowledge and family and examine the influence on zakat distribution effectiveness.

\subsection{Human Needs as Stipulated in Maqasid al-Syari'ah}

Maqasid is the purpose, objective or goal, while al-Syari'ah refers to the Islamic law. Maqasid al-Syari'ah, on the other hand refers to the higher objectives behind of Islamic law. According to Maqasid al-Syari'ah human has 5 basic needs comprising of preservation of religion (al-din), preservation of physical-self (al-nafs), preservation of knowledge (al-aql), preservation of family (an-nasb) and preservation of wealth (al-mal) (Mahyuddin \& Abdullah, 2011). Based on these 5 basic needs, Mohamad Saladin et al., (2010) proposed an Islamic Poverty Index (IPI) and articulated that these needs provide a holistic and comprehensive measurement for poverty. Rosbi and Sanep (2010) supported that human needs in the perspective Maqasid al-Syari'ah provide a fair and holistic assessment due to the inclusion of both monetary and non-monetary elements.

\subsubsection{Preservation of Religion}

Religion is the utmost important basic needs of humans in al-Syari'ah (Kamali, 2008). Muslims are required to act in accordance with al-Syari'ah. In all aspects of life, they must abide by the al-Syari'ah and seek blessing of Allah as to reach harmonious life, today and here after. Therefore, being Muslims, they are committed to fulfil 5 religious obligations such as performing daily prayers, fasting in the month of Ramadhan, paying zakat and performing hajj for those who can afford.

\subsubsection{Preservation of Physical-self}

Physical-self refers to the daily needs of which humans need healthcare, nutrition, quality of dwelling or shelter, amnesties, utilities, clothing and transportation. Al-Syari'ah imposes Muslims to meet these basic needs for themselves and their families (Mohamad Saladin, 2010). As such, they would not commit any harm that might be harmful to themselves, their families and other parties.

\subsubsection{Preservation of Knowledge}

Al-Syari'ah encourages Muslims to develop their intellectual levels and skills (Mujamid, 2005). These needs are inclusive of psychological factors such as stress management, education attainment and participation in social activities. Thus, possessing knowledge and intellectuality are essential for ones' benefits, also for family as well as for the society.

\subsubsection{Preservation of Family}

Al-Syari'ah also encourages Muslims to have family and offspring (Rosbi \& Sanep, 2010). They are also required to possess parenting skills, religious as well as ethical knowledge and thus instilling these elements in their children. Apart from that, it is an obligation of Muslims to protect the pride and dignity of their family and their ancestor.

\subsubsection{Preservation of Wealth}

Muslims are encouraged to own wealth and assets as much as they can, provided that the way of possession is not against the al-Syari'ah (Patmawati, 2006). Apart from wealth, Al-Syari'ah also encourages Muslim to work hard and have the ability to generate their income by not relying on others' assistance.

\subsection{Zakat Distribution Effectiveness}

Zakat distribution effectiveness is the ability or performance of a zakat program initiated by zakat institution in meeting its objective. In this study, the effectiveness of the program managed by zakat institutions is evaluated by using a performance tool, namely Balanced Score Card (Kaplan \& Norton, 1996). Balanced Score Card (BSC) is a performance measurement tool that assesses the effectiveness of a program based on non-financial and 
financial indicators. The BSC measurement has been used to evaluate various entities, either profit or non-profit organizations. This measurement is based on four components; customer satisfaction, internal process, knowledge worker and financial performance.

Customer satisfaction (CS) is the effort undertaken by the organization through initiated programs to satisfy its customer. The process starts after managers identify the potential customers in the target segments and consequently choose the required values to be delivered to customers. Meanwhile, knowledge worker (KW) emphasizes on innovation, creativity, competency and capability. The objectives of this dimension are to identify the human capital, information capital and the organizational ethical climate required to support the internal processes (Cohen et al., 2008). In addition, it also focuses on people and their attitude, knowledge, development and ability to learn and improve. Internal process (IP), on the other hand, identifies the critical process, skills, competencies and technologies that will deliver a value proposition to customers, current and future organizational success (Atkinson, 2000). Finally, the last component is financial performance (FP). The financial performance of the program is assessed on its achievement in meeting its targets to uplift the livelihood of zakat recipients. Hence, BSC is adopted due to its holistic features that look at multiple measures of performance.

\subsection{Empirical Studies on Zakat Distribution Effectiveness}

As noted, studies of zakat distribution effectiveness have been the interest of many scholars and researchers (Hairunnizam et al., 2004; Mujani, 2005; Ibrahim \& Salleh, 2006; Fuadah, 2006; Mohammad, 2006, Zakaria et al., 2010; Rosbi \& Sanep, 2011; Mahyudin \& Abdullah, 2011) and were assessed in relation to many indicators. Hairunnizam (2004) on the other hand, evaluated the effectiveness of zakat distribution based on the socio economics factors such as education, health, water and electric supplies as well as many other development indicators. The results of the study also indicated that the distribution of zakat to the recipients can give a significant impact to their level of income but small effect to the quality of life especially education and social relationship within community. Meanwhile, Ibrahim (2005) assessed the effectiveness of zakat distribution based on income and the direction of management. Additionally, Mahyudin and Abdullah (2011) evaluated the effectiveness based on the attainment of a minimum quality of life. Meanwhile, many studies examined the effectiveness of the distribution solely based on monetary indicator namely income (Johari, 2004; Ibrahim, 2005; Tarimin, 2005; Fuad, 2006; Mohammad, 2006; Zulkarnaen, 2008; Patmawati, 2009; Zakaria et al., 2010). These prior studies indicate that the distribution of zakat is classified as effective if the zakat recipients' incomes increase.

Nevertheless, apart from income, humans have also to fulfil other needs. Moreover, focusing on income alone can only reduce problems in the short term and at worst the problem of poverty persists (Rosbi \& Sanep, 2009). According to Saladin et al., (2010), the basic needs of human are not solely based on a uni dimensional factor such as income, but also on other factors as stipulated in the perspective of Maqasid al-Syari'ah. Maqasid al-Syari'ah stipulates 5 human needs that are essential to be fulfilled, which consists of religion, physical-self, knowledge, family and wealth. In fact, the emphasis on these 5 elements of humans needs is expected to reduce poverty not only at a state level but even at the national level. Mohamad Saladin et al., (2010) proposed the Poverty Islamic Index which is based on human needs in the perspective of Maqasid al-Syari'ah namely religion, physical-self, knowledge, family and wealth but they did not conduct any research to examine these basic needs. As far as the author is concerned, none of the study has evaluated the zakat distribution effectiveness based on human needs in the perspective of Maqasid al-Syari'ah and examines their relationship with zakat distribution effectiveness. Furthermore, none of the study evaluates zakat distribution effectiveness by using BSC.

To fill this gap, the current study examines the influence of humans needs in the perspective of Maqasid al-Syari'ah namely religion, physical-self, knowledge, family and wealth on zakat distribution effectiveness. Additionally, this study will evaluate zakat distribution effectiveness using the dimensions proposed by BSC. As such, the study formulates the following hypotheses and proposed the research model as indicated in Figure 1.

H1: The preservation of religion positively influences zakat distribution effectiveness

$\mathrm{H} 2$ : The preservation of physical-self positively influences zakat distribution effectiveness

H3: The preservation of knowledge positively influences zakat distribution effectiveness

H4: The preservation of family positively influences zakat distribution effectiveness

H5: The preservation of wealth positively influences zakat distribution effectiveness

Figure 1 depicts the structure of the proposed model. The proposed model proposes that 5 dimensions of human needs in the perspective of Maqasid al-Syari'ah namely the preservations of religion, physical-self, knowledge, family and wealth (exogenous constructs) influence the endogenous construct (zakat distribution effectiveness). 
In addition ' $\mathrm{e}$ ' in Figure 1 denotes the error term while ' $\mathrm{x}$ ' is the question item used to measure the variable.

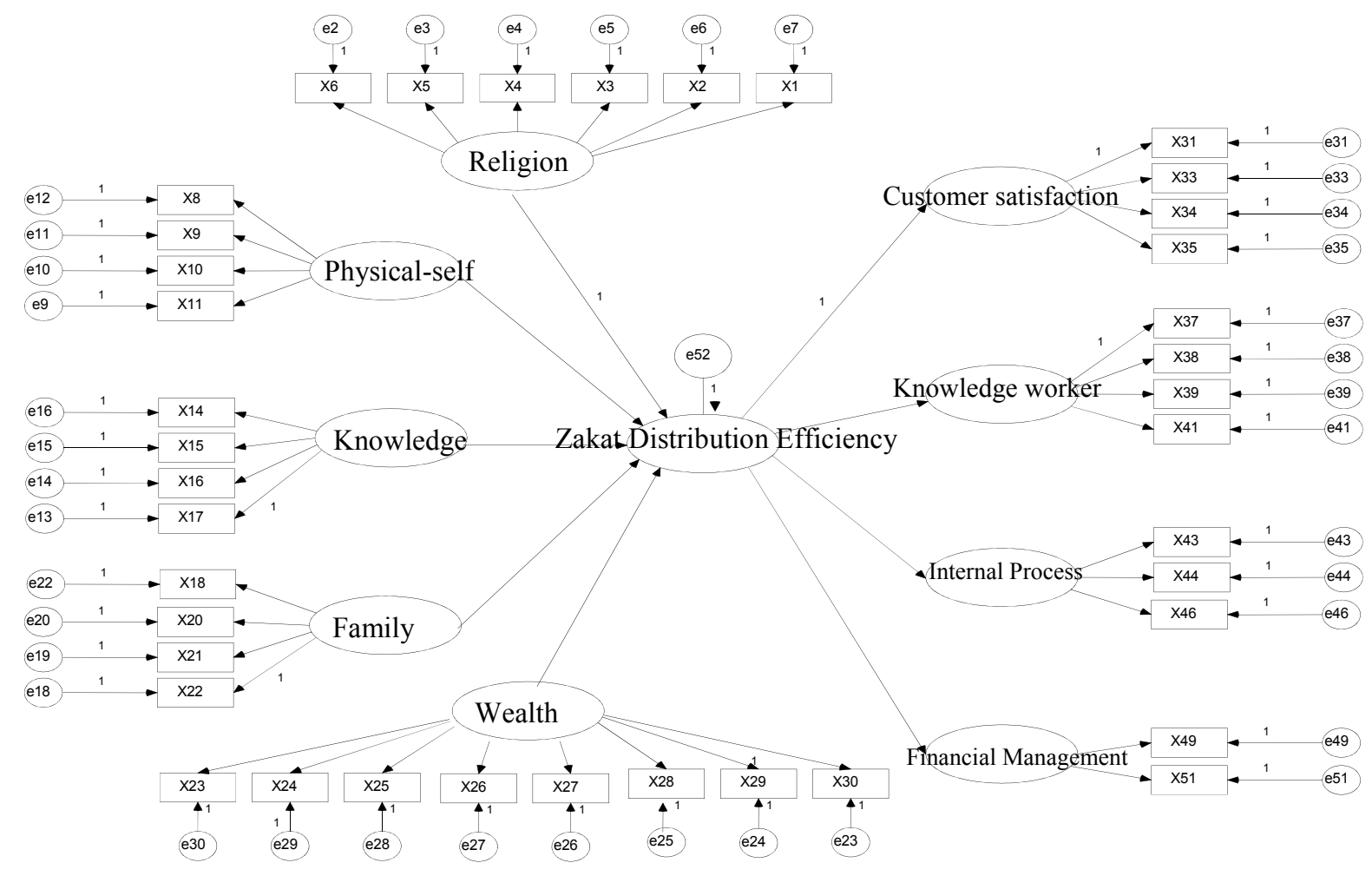

Figure 1. Proposed model

\section{Method}

\subsection{Questionnaire and Sample}

This study is carried out to examine the influence of human needs in the perspective of Maqasid al-Syari'ah on zakat distribution effectiveness. The State of Kelantan is chosen because it is the poorest state in peninsular Malaysia and the majority of the poor are Muslims (Statistic, 2008). Meanwhile, the responsibility for the distribution of zakat fund is given to state religious council namely Majlis Agama Islam Kelantan (MAIK). To date, MAIK has initiated 18 zakat programs. Of the 18 programs, the study decides to examine the zakat recipients of two programs namely business assistance and living skill courses in Malaysia. These two programs are chosen because the programs are expected to accelerate positive economic values and thus have significant impacts in uplifting the zakat recipients' living standard in the long run. On the other hand, the remaining 16 programs are expected to provide assistance on short term basis where once given, the funds would be spent to make ends meet.

The sampling frame is based on zakat recipients' listing of business assistance program issued by MAIK. According to the listing, from 1 September 2010 to 1 February 2012 there are about 311 zakat recipients. Meanwhile, for living skill program, the listing stated that there are approximately 214 trainees who attended three programs for five enrolments; January 2009, October 2009, June 2010, February 2011 and October 2011. Approximately 350 sets of a questionnaire are sent to the respondents: 200 trainees of living skill program and 150 zakat recipients of business assistance program (selected via simple random sampling) with 315 people responded, accumulating to $91.43 \%$ response rate.

\subsection{Measurements}

The zakat distribution effectiveness is operationalized based on BSC that consists of 4 dimensions namely customer satisfaction, internal process, knowledge worker and financial performance. The construct is evaluated based on questions adapted from Salwana et al., (2012). Meanwhile, questions to measure human needs in the perspective Maqasid al-Syari'ah are adapted from Rosbi and Sanep (2010). Constructs are operationalized using 7-point Likert scales, ranging from strongly disagree (1) to strongly agree (7). In total, 30 items are used to measure constructs. Out of 30 items, 7 items measure the preservation of religion, 5 items measure the 
preservation of physical life, 5 items measure the preservation of knowledge, 5 items measure the preservation of family as well as 8 items that measure the preservation of wealth. Meanwhile, zakat distribution effectiveness is measured by 21 items. Out of these total items, 6 items measure customer satisfaction, 5 items measure internal process, 5 items measure knowledge worker and finally 5 items measure financial performance.

Statistical Science Statistical Package (SSPS) version 20 is utilised to assess preliminary data, data screening as well as frequency and reliability analyses. This study then adopts a one stage approach of Structural Equation Modelling (SEM) using AMOS (Analysis of Moment Structure), whereby it assesses both the measurement and structural model simultaneously.

\section{Results}

The results indicate that the number of ratio of females' respondents is higher than males (female 173 or $54.06 \%$, while males are 147 or $45.94 \%$ ). Additionally, 189 or $59.06 \%$ of the respondents are married, 131 or $40.94 \%$ are single and the remaining 55 or $14.4 \%$ are divorced woman, widow and widower. In terms of age, 128 or $40.00 \%$ are less than 25 years, 80 or $25.00 \%$ are between 35 to 44 years, 54 or $16.88 \%$ are between 25 to 34 years, 48 or $15.00 \%$ are between 45 to 55 years and finally 10 or $3.12 \%$ are more than 55 years. Further, it is found that 170 or $53.13 \%$ of the respondents have a minimum education of SPM, follow by certificate ( 82 or $25.63 \%$ ), diploma (51or $15.94 \%$ ) and SRP or PMR (17 or $5.30 \%$ ). Finally, majority of the respondents have dependents ranging from 4 to 8 people (164 or $51.25 \%$ ), follow by those who have dependents ranging from 1 person to 3 people ( 75 or $23.44 \%$ ), no dependent ( 65 or $20.31 \%$ ), and 16 or $5.00 \%$ have dependents of 9 to 12 people.

Further, the study performs one stage approach of Structural Equation Modelling (SEM) using AMOSS version 20 of which the measurement and structural model are performed simultaneously. The results indicate that the initial measurement needs to be respecified, even though all standardized parameter estimates are all significant $(p<0.001)$. After deleting a few question items, the model indicates that the chi-square is significant $\left(\chi^{2}=\right.$ 874.738, $\mathrm{df}=50, p=0.000, \mathrm{~N}=315$ ). The TLI $=0.952, \mathrm{NFI}=0.915, \mathrm{CFI}=0.967, \mathrm{RMSEA}=0.067$. Even though the chi-square is significant, the fitted indexes values suggest that the model fit adequately to the data. In addition, the inter correlations among the constructs are lesser than 0.85 , demonstrating a lack of discriminant validity. All constructs indicate that the Cronbach Alphas are above 0.70. Meanwhile, construct reliability (CR) and average variance extract (AVE) are above 0.50. Furthermore, all the standardized factor loadings for the constructs are all higher than the recommended level of 0.50 . This indicates that the standardized parameter estimates for these measures are deemed to be statistically significant $(p<0.001)$, providing unidimensionality scales for each of these factors. 


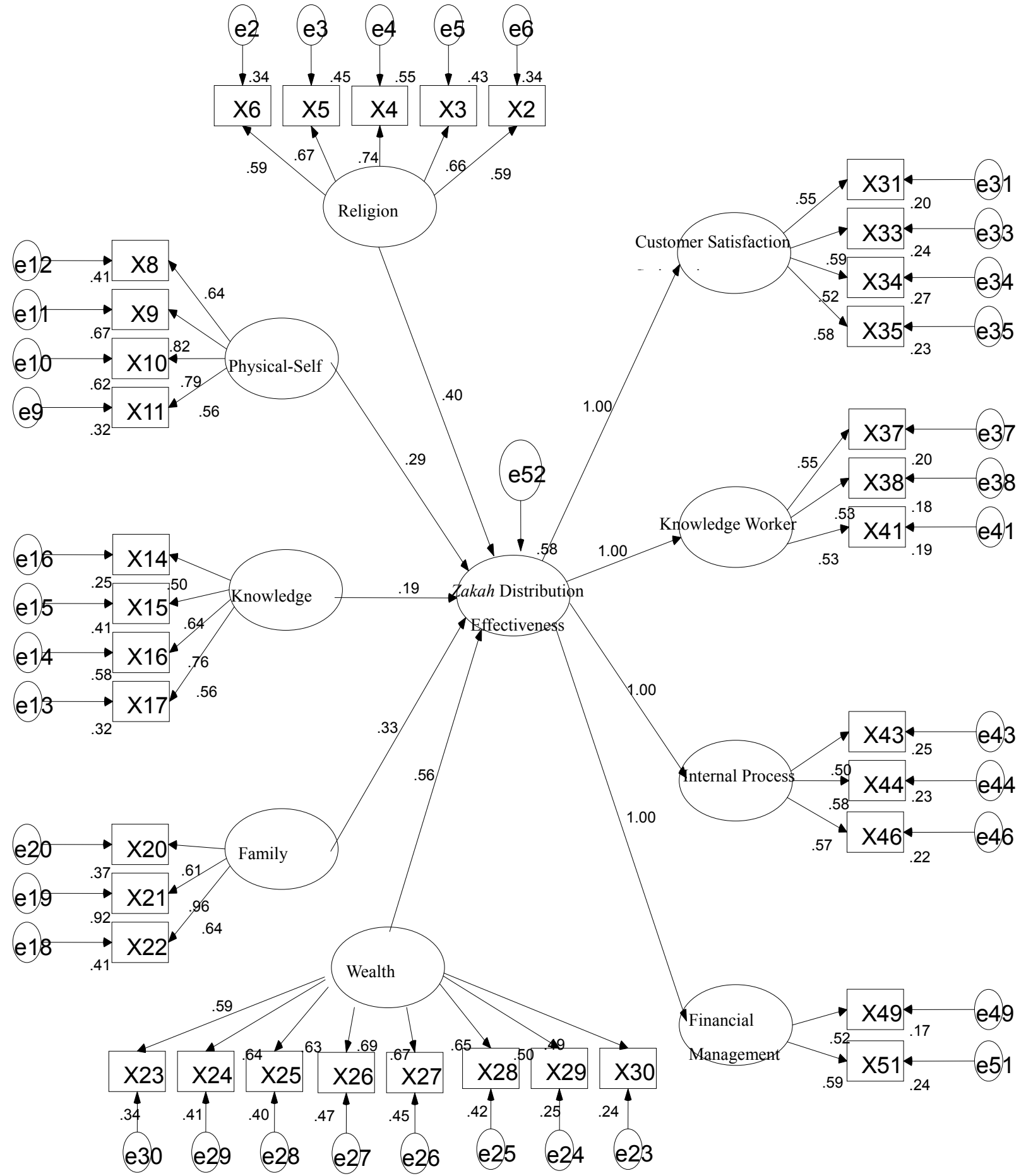

Figure 2. Results of the proposed model

With regards to the importance of each elements, standardized coefficients are useful indicators for manifested dimensions. From all 5 dimensions of Maqasid al-Syari'ah, wealth shows the strongest influence follows by religion, family, physical-self and finally knowledge. Table 2 shows the findings for the relationship between 5 elements of human needs in the perspective of Maqasid al-Syari'ah on zakat distribution effectiveness, which to answer the hypothesis. The results show that all the 5 elements of human needs in the perspective of Maqasid al-Syari'ah have strong positive influence on zakat distribution effectiveness. In addition, the $R^{2}$ also shows a high value of 0.58 . 
Table 1. Results of the proposed model

\begin{tabular}{lccccc}
\hline Casual Path & Hypothesis & Expected Sign & Path Coefficient & t-value & Assessment \\
\hline $\begin{array}{l}\text { Religion } \rightarrow \\
\text { Zakat } \text { Distribution Effectiveness }\end{array}$ & $\mathrm{H} 1$ & + & 0.397 & 5.695 & Support \\
$\begin{array}{l}\text { Physical- Self } \rightarrow \\
\text { Zakat } \text { Distribution Effectiveness }\end{array}$ & $\mathrm{H} 2$ & + & 0.288 & 4.606 & Support \\
$\begin{array}{l}\text { Knowledge } \rightarrow \\
\text { Zakat } \text { Distribution Effectiveness }\end{array}$ & $\mathrm{H} 3$ & + & 0.190 & 2.379 & Support \\
$\begin{array}{l}\text { Family } \rightarrow \\
\text { Zakat } \text { Distribution Effectiveness }\end{array}$ & $\mathrm{H} 4$ & + & 0.334 & 5.104 & Support \\
$\begin{array}{l}\text { Wealth } \rightarrow \\
\text { Zakat } \text { Distribution Effectiveness }\end{array}$ & $\mathrm{H} 5$ & + & 0.560 & 5.908 & Support \\
\hline
\end{tabular}

\section{Discussion}

The findings show that all the humans needs in the perspective of Maqasid al-Syari'ah namely religion, physical-self, knowledge, family and wealth positively influence zakat distribution effectiveness. The findings supported the prediction when the coefficient of determination is high for all dimensions, in which about $58 \%$ of humans needs in the perspective of Maqasid al-Syari'ah can be predicted by zakat distribution effectiveness $\left(R^{2}=0.58\right)$. Therefore, zakat institutions should focus on fulfilling all the 5 elements of these human needs if they intend to meet the effectiveness in zakat distribution.

For each element of human needs, it indicates that every construct has different degree of intensity in influencing the zakat distribution effectiveness. Wealth appeared to be the strongest construct. To maximise zakat distribution effectiveness, zakat institutions should focus more on programs that could improve zakat recipients' economic hardship as well as generate their income. In other words, the programs should not only help them to make their ends meet but also could free them from poverty or even being able to pay zakat.

The second important construct is religion. Here, zakat institutions should conduct religious programs to instil in zakat recipients' mind of their obligation and responsibilities to the religion for the good of themselves, families as well to the society.

In addition to wealth and religion, the third important construct is family. The findings provided an implication to the institution to focus on uplifting the livelihood and welfare of zakat recipients' family by providing them protection especially when they are having problem or in despair. The institution should also motivate them to work hard for the comfort of their families, provide counseling whenever necessary and support the education of their children in terms of social and financial.

Meanwhile, the fourth important construct is physical-self. To fulfill these needs, the institution should focus on exposing the zakat recipients to training and motivation programs. The programs could cultivate the recipients' awareness of their potential, strength, opportunities and self-confidence and thus helping them to socialize in the society.

Finally, the fifth and weakest construct is knowledge. Even though this construct provided the least degree of intensity, it should not be side-lined. With regard to this, the institution should equip the zakat recipients with knowledge that enables them to make their own living. Among the programs is entrepreneurship, of which it would assist the zakat recipients become successful entrepreneurs. In addition, skill and technical programs are proven to help them in generating their own income. Hence, to ensure zakat distribution is effective, the cooperation from both parties namely zakat institutions and zakat recipients is crucial. If only one party is serious without cooperation from the other party, the zakat distribution will fail to achieve its objective of alleviating poverty in the society.

\subsection{Limitation and Suggestion for Future Research}

The limitation of this study is that the study only focuses on the zakat programs carried out by Kelantan State Religious Council known as MAIK. It is suggested that a comparative study to be conducted, whereby other zakat programs of other state religious council or even of other countries are investigated. The findings may 
provide different results due to the culture differences and thus providing different implication to the respective zakat institutions.

Another limitation is the study only investigated 2 out of 18 programs of Majlis Agama Islam Kelantan (MAIK). In order to increase the validity of the results, it is suggested that similar studies are conducted to examine the remaining programs. It would be interesting to analyze the consistency or the differences of the findings that provide a better understanding on the impact of the humans needs on zakat distribution effectiveness.

\subsection{Conclusion}

This study concludes that all 5 elements of human needs in the perspective Maqasid al-Syari'ah have strong influence on zakat distribution effectiveness. Among the elements, the preservation of wealth was the most important construct followed by the preservations of religion, family and physical-self. The weakest construct was the preservation of knowledge. The findings of the study provided a useful insight to zakat institutions to be more pro-active in formulating programs to uplift the livelihood of the zakat recipients. Last but not least, a proper, transparent and effective distribution of zakat is expected to provide a positive impact on equitable distribution of wealth to the Muslim society and thus reducing the income gap between the rich and the poor.

\section{Acknowledgements}

The authors would like to express appreciation to Accounting Research Institute, Universiti Teknologi MARA and Ministry of Higher Learning of Malaysia for funding the research.

\section{References}

Ahmad, S., Wahid, H., \& Nor, M. A. M. (2006). Penswastaan institusi zakat dan kesannya terhadap pembayaran secara formal di Malaysia (Privatization of zakat institutions in Malaysia and its effect on formal payment). International Journal of Management Studies, 13(2), 75-96.

Ali, M. (2008). Perception of academicians towards zakat administration particularly zakat distribution: The case of Selangor and Kelantan. Unpublished Master Thesis, International Islamic University Malaysia, Kuala Lumpur.

Atkinson, R. (2000). Combating social exclusion in Europe. The New Urban Policy Challenge, Urban Studies, 37.

Bagozzi, R. P., \& Yi, Y. (1988). On the evaluation of structural equation models. Journal of the Academy of Marketing Science, 16(1), 74-94. http://dx.doi.org/10.1007/BF02723327

Bakar, M. A. (2011). Towards achieving the quality of life in the management of zakat distribution to the rightful recipients (the poor and needy). International Journal of Business and Social Sciences, 2(4), 237-245.

Bakar, M. A., \& Ghani, A. A. (2011). Towards achieving the quality of life in the management of zakat distribution to the rightful recipients (the poor and needy). International Journal of Business and Social Science, 2(4), 237-245.

Cohen S., Thuiraasi D., \& Kandilarou M. (2008). Performance parameters interrelations from a balanced scorecard perspective: An analysis of Greek companies. Managerial Auditing Journal, 2(2), 485-503. http://dx.doi.org/10.1108/02686900810875307

Department of Statistics Malaysia. (2010). Population distribution and basic demographic characteristics. Retrieved from http://www.statistic.gov.my/portal/download_population/files/cencus2010/Taburan_penduduk_dan_ciri-ciri asas demographi.pdf

Economic Planning Unit. (2009). The highest hardcore poor.

Ibrahim, F., \& Salleh, M. F. M. (2006). Stochastic frontier estimation: An application to local government in Malaysia. Malaysian Journal of Economic Studies, 43(1), 42-55.

Ibrahim, P. (2006). Economic role of zakat in reducing inequality and poverty in Selangor. Unpublished Phd Thesis. Faculty of Economic and Management, Universiti Putra Malaysia

Ibrahim, P. (2008). Pembangunan ekonomi melalui agihan zakat: Tinjuan Empirikal. Syariah Journal, 16(2), 223-244.

Islamic Relief Worldwide Definition of poverty. (2008). Birmingham, UK.

Ismail, S., Sidid, S. S. M., \& Yusoff, K. H. M. (2012). The use of balanced scorecard in school project to reduce absenteeism: A case of SMK Tanah Merah 2, Kelantan. Unpublished project paper. Universiti Teknologi 
MARA, Kelantan.

Jamain, J. (2004). A secret recipe: Steps in Entrepreneurial development success. Policy and Development Success Journal, 1(1), 111-122.

JAWHAR. (2007). Pelan Strategik JAWHAR 2007-2011. Putrajaya Prime Minister Office. Retrieved from http://www.jawhar.gov.my

Johan, F. (2004). Keberkesanan zakat dalam mengatasi masalah kemiskinan di negeri Melaka. Unpublished Master Dissertation. Universiti Malaya.

Kamali, M. H. (2008). Maqasid al-Shari'ah made simple. The International Institute of Advanced Islamic Studies (IAIS), Malaysia,

Kaplan, R. S., \& Norton, D. P. (1996). The balanced score card: Translating strategy into action. HBS Press, Boston.

Laporan Ekonomi - Negeri Kelantan Darul Naim 2010-2011. (2012). Unit Perancang Ekonomi Negeri Kelantan, Pejabat Setiausaha Kerajaan, Kelantan.

Malaysia. (2006). Rancangan Malaysia ke sembilan 2006-2010. Percetakan Nasional, Kuala Lumpur.

Maslow, A. H. (1970). Motivation and personality (2nd ed.). New York: Harper \& Row.

Mohamad Saladin, M., Rasool, A., Salleh, A. M., \& Harun, M. F. M. (2010). Poverty measurement in Malaysia zakat institutions: non-Monetary indicators. Zakat Transformation: From Subsistence to productive. Proceeding of the $4^{\text {th }}$ ISDEV International Islamic development, Universiti Sains Malaysia, 21-22 September 2010.

Nolan B., \& Whelan, C. T. (2010). Using non-monetary deprivation indicators to analyse poverty and social exclusions: Lesson from Europe. Journal of Policy Analysis and Management Spring, 15(2), 140-143.

Rahman, R. A., \& Ahmad, S. (2010). Keperluan asas berdasarkan Maqasid al-Syariah: Ke arah pencapaian matlamat dan penilaian komprehensif agihan zakat- The $4^{\text {th }}$ ISDEV International Islamic Development Management Conference (IDMAC 2010) Universiti Sains Malaysia, $21^{\text {st }}-22^{\text {nd }}$ December 2010.

Rahman, R. A., \& Ahmad, S. (2011). The World Universities $1^{\text {st }}$ Conference 2011, Zakat Research Institute of Malaysia of Malaysia (IKaZ), UiTM, 22 - 24 November 2011.

Rahman, R. A., Ahmad, S., \& Tahir, H. M. (2009). Keberkesanan agihan zakat mengikut perspektif maqasid al syariah. Kertas Kerja dibentang pada Seminar Antarabangsa muamalat kewangan ekonomi islam. Universiti Kebangsaan Malaysia, 21 October 2009.

Roscoe, J. T. (1975). Fundamental research statistics for the behavioural sciences (2nd ed.). New York, Holt, Rihehart and Winston.

Tarimin, M. (2005). Golongan penerima zakat: Agihan dana zakat secara lebih berkesan. Pusat Penerbitan Universiti (UPENA), Universiti Teknologi MARA, Shah Alam.

Unit Perancang Ekonomi Negeri Kelantan. (2011). Laporan ekonomi negeri Kelantan. Pejabat Setiausaha Kerajaan Negeri Kelantan Darulnaim.

Wagle, U. (2005). Multidimensional poverty measurement with economic well-being, capability and social inclusion: A case from Katmandu Nepal. Journal of Human Development, 6(1), 210-225.

Wagle, U. (2007). Poverty in Katmandu: What do subjective and objective economic welfare concepts suggest. Journal of Economic Inequality, 5(1), 96-113. http://dx.doi.org/10.1007/s10888-006-9026-8

Wagle, U. (2008). Multidimensional poverty: Alternative measurement approach for the United States. Social Science Research, 37(2), 50-64. http://dx.doi.org/10.1016/j.ssresearch.2007.06.013

Yusoff, Z. (2008). Pengurusan zakat dan peranannya dalam menangani kemiskinan di Kelantan. In D. Hafidhudin (Ed.), The power of zakat studi perbandingan pengelolaan zakat Asia Tenggara. UIN Malang Press.

\section{Copyrights}

Copyright for this article is retained by the author(s), with first publication rights granted to the journal.

This is an open-access article distributed under the terms and conditions of the Creative Commons Attribution license (http://creativecommons.org/licenses/by/3.0/). 